\title{
Effects of storage temperatures and 1-MCP treatment on postharvest quality of green olives
}

Ali Akbar Ramin

Department of Horticulture, College of Agriculture, Isfahan Univ. Technol, Isfahan 8415683111, Iran

aa-ramin@cc.iut.ac.ir

\section{${ }^{*}$ Correspondence and reprints}

Received 20 April 2007 Accepted 10 July 2007

Fruits, 2007, vol. 62, p. 383-390 (C) 2007 Cirad/EDP Sciences All rights reserved DOI: $10.1051 /$ fruits:2007036 www.fruits-journal.org RESUMEN ESPAÑOL, p. 390

\section{Effects of storage temperatures and 1-MCP treatment on postharvest quality of green olives.}

Abstract - Introduction. Olive processing in producing countries, such as Iran, is often not well synchronized with crop harvests due to the number and size of the oil-extraction facilities. After harvest, olives might be piled in heaps and stored at ambient temperatures for up to several weeks and, during this period, the greatest deterioration takes place. Therefore, the green olive processing industry is interested in the use of an alternative to the above pre-processing storage method for fresh olives. Materials and methods. Green olives cvs. Blady, Conservolea Mission and Shengeh were harvested at the mature green stage and stored at $(5,10 \text { and } 20)^{\circ} \mathrm{C}$ for $10-15$ weeks to evaluate their postharvest physiology and quality changes. In the second year of the experiment, olives were treated with 1-MCP at concentrations of $(0.45,0.9$ and 1.8$) \mathrm{\mu L} \cdot \mathrm{L}^{-1}$ at $20^{\circ} \mathrm{C}$ for $24 \mathrm{~h}$ and stored at $5{ }^{\circ} \mathrm{C}$. Olive quality was measured periodically for skin color, fresh firmness, mass loss and fruit deterioration. Results and discussion. Generally, storage of olive fruits at $(5,10 \text { and } 20)^{\circ} \mathrm{C}$ caused a decrease in flesh firmness, but fruit softening was faster in fruits stored at $(20$ and 10$){ }^{\circ} \mathrm{C}$ than in fruits at $5{ }^{\circ} \mathrm{C}$. Olives stored for $60 \mathrm{~d}$ at $5{ }^{\circ} \mathrm{C}$ showed no symptoms of chilling injury whatever the cultivar. Olive cultivars retained satisfactory firm flesh above $2 \mathrm{~kg}$ for $60 \mathrm{~d}$ at $5{ }^{\circ} \mathrm{C}, 30 \mathrm{~d}$ at $10^{\circ} \mathrm{C}$ and $15 \mathrm{~d}$ at $20^{\circ} \mathrm{C}$. After $60 \mathrm{~d}$ of storage, red skin color development did not progress much with fruits stored at $5{ }^{\circ} \mathrm{C}$, but there was a significant difference with the other temperature treatments. However, cv. Shengeh developed red skin color greater and sooner than other cultivars did. In the second year of the experiment, 1-MCP treatment effectively reduced loss of firmness for fruits stored at $5^{\circ} \mathrm{C}$ for 15 weeks. Application of (0.9 and 1.8) $\mu \mathrm{L} 1-\mathrm{MCP} \cdot \mathrm{L}^{-1}$ was sufficient to delay significantly olive softening and color changes $(P<0.05)$, compared with control untreated fruits. Conclusion. Conservolea, Mission and Blady olive cvs. can be stored for up to $60 \mathrm{~d}$ at $5{ }^{\circ} \mathrm{C}$ and this could be extended to 15 weeks when fruits are treated with $(0.9$ and 1.8$) \mu \mathrm{L} 1-\mathrm{MCP} \cdot \mathrm{L}^{-1}$ before storage.

Iran Islamic Republic / Olea europaea / fruits / deterioration / storage / postharvest losses / environmental temperature / keeping quality

\section{Effets de la température de stockage et d'un traitement au 1-MCP sur la qualité après récolte des olives vertes.}

Résumé - Introduction. Le traitement de l'olive dans les pays producteurs comme l'Iran n'est souvent pas bien synchronisé avec sa récolte du fait du nombre et de la taille des installations dédiées à l'extraction d'huile. Après leur récolte, les olives peuvent être empilées en tas et stockées à la température ambiante pendant plusieurs semaines et, au cours de cette période, de sévères détériorations ont lieu. Par conséquent, l'industrie de la transformation de l'olive verte est intéressée par un prétraitement pouvant remplacer cette façon de faire pour le stockage de l'olive fraîche. Matériel et méthodes. Des olives vertes des cvs. Blady, Conservolea, Mission et Shengeh ont été récoltées au stade vert mâture et stockées à $(5,10 \text { et } 20)^{\circ} \mathrm{C}$ pendant $(10 \mathrm{ou} 15)$ semaines pour évaluer leur physiologie après récolte et l'évolution de leur qualité. Lors d'une deuxième année d'expérimentation, des olives ont été traitées au 1-MCP utilisé aux concentrations de $(0,45,0,9$ et 1,8$) \mu \mathrm{L} \cdot \mathrm{L}^{-1}$ à $20^{\circ} \mathrm{C}$ pendant $24 \mathrm{~h}$ et stockées à $5^{\circ} \mathrm{C}$. La qualité des olives a été mesurée périodiquement par l'évolution de la couleur de la peau, ainsi que par la fermeté de la chair, la perte de poids et la détérioration des fruits. Résultats et discussion. Généralement, le stockage des olives à $(5,10 \text { et } 20)^{\circ} \mathrm{C}$ a entraîné la diminution de la fermeté de chair, mais le ramollissement du fruit a été plus rapide pour les fruits stockés à $(20 \text { et } 10)^{\circ} \mathrm{C}$ que pour ceux placés à $5{ }^{\circ} \mathrm{C}$. Les olives stockées pendant 60 jours à $5^{\circ} \mathrm{C}$ n'ont montré aucun symptôme des dommages dus au froid quel qu'ait été le cultivar. Les olives des différents cultivars ont gardé une chair ferme satisfaisante pendant 60 jours à $5^{\circ} \mathrm{C}, 30$ jours à $10^{\circ} \mathrm{C}$ et 15 jours à $20^{\circ} \mathrm{C}$. Après 60 jours de stockage, le développement de la couleur rouge de la peau a peu progressé dans des fruits stockés à $5^{\circ} \mathrm{C}$, mais il a présenté des différences significatives aux autres températures. Cependant, pour le cv. Shengeh, l'évolution de la couleur rouge de la peau a été plus intense et plus précoce que pour les autres cultivars. Lors de la deuxième année d'expérience, le traitement au 1-MCP a effectivement réduit le ramollissement de la chair pour des fruits stockés à $5^{\circ} \mathrm{C}$ pendant 15 semaines. Les applications $(0,9$ et 1,8$) \mu \mathrm{L} 1-\mathrm{MCP} \cdot \mathrm{L}^{-1}$ ont été suffisantes pour retarder significativement ce ramollissement et le changement de couleur des olives $(P<$ 0.05 ), comparés aux caractéristiques des fruits témoins non traités. Conclusion. Les olives des cvs. Conservolea, Mission et Blady peuvent être stockées jusqu'à 60 jours à $5^{\circ} \mathrm{C}$ et leur conservation pourrait se prolonger jusqu’à 15 semaines si les fruits étaient traités avec $(0,9$ ou 1,8$) \mu \mathrm{L} 1-\mathrm{MCP} \cdot \mathrm{L}^{-1}$ avant stockage. Iran République islamique / Olea europaea / fruits / détérioration / stockage / perte après récolte / température ambiante / aptitude à la conservation 


\section{Introduction}

Olive tree, Olea europaea L., is a member of the Oleaceae family. It is a small tree native to the eastern part of the Mediterranean region. The part used for consumption is the fleshy mesocarp from which edible oil is extracted; nevertheless, fruit may be pickled and the mesocarp and exocarp eaten [1]

In producing countries such as Iran, olive processing is often not well synchronized with crop harvests due to the number and size of the oil-extraction facilities. In Iran, a number of olive tree cultivars are cultivated for processing as table olives. Fruit are harvested mature-green or black depending on the cultivar. Therefore, after harvest, olives might be piled in heaps and stored at ambient temperatures for up to several weeks before processing [2, 3] and, during this period, great deterioration takes place [4]. Pressure within the olive pile during storage can cause fluid secretion from the fruit, which can provide an optimum medium for growth of fungi and bacteria [4]. Under these conditions, anaerobiosis can occur in the inner part of the pile while aerobic losses occur in the outer part [5]. Furthermore, heat production from respiratory activity may accelerate the deterioration of the fruit and eventually cause the breakdown of cell structure [6]. The quality of the processed product depends on the skin color and flesh firmness of the raw product at the time of processing. The disposal of brine requires wastewater treatment, while the effect of brine on final product quality has not been measured. In addition, only fresh olives can be processed. Therefore, the green olive processing industry is interested in the use of an alternative to the above pre-processing storage method for fresh olives.

There are a limited number of reports on olive storage without brine. It was found that there is a great deal of variation in storability between cultivars even when grown in the same area. Mature-green olives are chilling-sensitive when kept long enough at temperatures below $5^{\circ} \mathrm{C}$, while fruit of some cultivars can be damaged at temperatures as high as $10^{\circ} \mathrm{C}[7,8]$. Storage of green Manzanillo olives at temperatures below $5{ }^{\circ} \mathrm{C}$ causes chilling injury, and thus the minimum safe storage temperature is $5{ }^{\circ} \mathrm{C}$ [9]. However, black-ripe olives might tolerate lower temperatures without incidence of chilling injury, as found in avocado fruit [10]. Nevertheless, the severity of chilling injury depends on time-temperature, cultivar, maturity and atmospheric composition. Red skin color appeared faster at $7.5^{\circ} \mathrm{C}$ than at $5^{\circ} \mathrm{C}$ in Conservolea olives, as shown by the decreasing $C^{*}$ values measured [11]. Red color development progressed with storage, especially after $45 \mathrm{~d}$ at $5^{\circ} \mathrm{C}$ or before $30 \mathrm{~d}$ at $7.5^{\circ} \mathrm{C}$ [12].

Non-climacteric fruits do not show a dramatic respiration or ethylene burst, nor do they continue to develop after harvest. Instead they undergo a senescence process which is parallel to some of the same processes occurring in ripening fruit [13]. However, slowing the process of ripening and senescence extends the storage and the shelf-life of fresh fruit and vegetables. Olives produce very little ethylene but are moderately sensitive to ethylene action above $1 \mathrm{ppm}$ that may cause loss of green color and flesh firmness [14]. It has been demonstrated that the inhibition of the ethylene action delays ripening and senescence in several species of fruits and vegetables [15, 16]. Recently a new tool, 1-methylcyclopropene (1-MCP), has been added to the methods used for extending storage life and quality of plant tissue. The success of the 1-MCP treatment depends on the method of application, duration and concentration as well as commodity factors such as maturity stage, cultivar and atmosphere ${ }^{1}$. However, it is not clear if 1-MCP will be of benefit for mature green olive cultivars grown in central Iran, Isfahan.

The objective of our study was to evaluate effects of storage temperatures and 1MCP treatments on fruit postharvest quality, mainly skin color and flesh firmness, for four commercially important table olive cultivars.

\footnotetext{
${ }^{1}$ See www.hort.cornell.edu, 2003: Watkins C.B., Miller W.B., A summary of physiological processes or disorders in fruit, vegetables and ornamental products that is delayed or decreased, increased or unaffected by application of 1-methylcyclopropene.
} 


\section{Materials and methods}

Green unripe olives (Olea europaea) cvs. Blady, Conservolea, Mission and Shengeh were hand-harvested on 21st and 18th of September 2005 and 2006, respectively, from trees in the same orchard that received the same cultural practices as olive tree plantations located around the Ghum province, Fadac Garden (central Iran). Sampling was achieved from three adjacent trees and from different parts of each tree, so as to minimize the effect of watering, sun exposure and differences related to different maturation stages. Olives were immediately transported to the Postharvest Laboratory, at Isfahan University of Technology, Isfahan, and sorted to obtain fruits of uniform size and color.

In 2005, $1 \mathrm{~kg}$ of sample of each cultivar was weighed, placed into 2-L glass jars and stored at constant temperatures of $(5,10$ and 20) ${ }^{\circ} \mathrm{C}$. Three replications were applied at each temperature treatment. Relative humidity was controlled at ( 85 to 95 )\% and air temperatures in all rooms were scanned and controlled to within $\pm 1{ }^{\circ} \mathrm{C}$.

Samples of 30 olives were randomly removed from each temperature treatment and cultivar: 12 olives were used for firmness studies and 18 olives were used for fluorescence and color measurements. Observations of decay, firmness, fluorescence and color value were made over $60 \mathrm{~d}$, at an average interval of 2 weeks, during the course of the experiment.

Samples of 20 olives from each cultivar were analyzed to determine initial firmness, color and the maximum quantum yield of photosystem II (PSII). The percentages of decayed olives with visible mycelia growth and those exhibiting physiological disorders were determined.

Flesh firmness was measured with a Fruit Hardness Tester Model 10576, OSK, Japan, equipped with a modified $5-\mathrm{mm}$ conic diameter and 2-mm-long tip plunger. Flesh firmness measurements were taken after careful removal of skin and penetration of the flesh to about $2 \mathrm{~mm}$ (flesh width ranged from 3-4 mm). Two firmness measurements were collected from opposite sides of each olive among 12 olives per replicate. Olive firmness was reported in $\mathrm{kg}$ units.

External skin color (opposite side) was periodically measured with a Minolta chromameter (Model CR-200, Minolta, Camera Co., Japan,) calibrated with a white standard $(y=94.3 ; x=0.3142 ; z=0.3211)$. Values of $a^{*}$ and $b^{*}$ readings were taken and color was reported as $a^{*}$ (green-red) and $b^{*}$ (blue-yellow). Change in the Hue angle $\left(H^{\circ}\right)$ was calculated as $\mathrm{h}=\arctan \left[b^{*} / a^{*}\right.$, which can be used effectively for visualizing the color of fruits [17]. External color was measured on 10 olives for each replicate.

Chlorophyll fluorescence of olive fruits was measured using a plant efficiency analyzer (PEA, Hansatech, Ltd.). When using a PEA, the fruit sample is darkened with a lightweight plastic leaf clip clipped for $6 \mathrm{~min}$ before the measurement. During measurement, the PEA sensor unit is held over the clip and the shutter opened. A single buttonpress activates the high intensity of the LED array of the sensor head which provides a maximum light intensity of $3000 \mu \mathrm{mol} \cdot \mathrm{m}^{-2} \cdot \mathrm{s}^{-1}$. Maximal PSII photochemical efficiency $\left[\mathrm{F}_{\mathrm{v}} / \mathrm{F}_{\mathrm{m}}\right]$, the ratio of variable fluorescence $\left(\mathrm{F}_{\mathrm{V}}\right)$ to maximum fluorescence $\left(F_{m}\right)$, was calculated automatically. Measurement was made from opposite sides of each olive. This technique has recently been used for postharvest horticultural communities for better indication of storage environments [18].

In the second year of the experiment (2006), olives were treated with 1-MCP at concentrations of $(0.45,0.9$ and 1.8$) \mu \mathrm{L} \cdot \mathrm{L}^{-1}$ (according to the manufacturer's procedure) at $20^{\circ} \mathrm{C}$ for $24 \mathrm{~h}$. After treatment with 1-MCP, untreated control and 1-MCP-treated fruits were randomly divided into bags of 30 fruits each and stored at $5{ }^{\circ} \mathrm{C}$. Quality parameters were evaluated on the $3 \mathrm{rd}$, 6th, 9th, 12th and 15th weeks after harvest.

The experiment was set up as a completely randomized design with three replications of each treatment. All statistical procedures were performed using MSTAT-C. Data were subject to ANOVA, and least significant differences $\left(\mathrm{LSD}_{\mathrm{S}}\right)$ were determined at $P<0.05$ to compare means. 
Figure 1.

Changes in flesh firmness of fruits from four olive cultivars during storage at three temperatures for $60 \mathrm{~d}$.
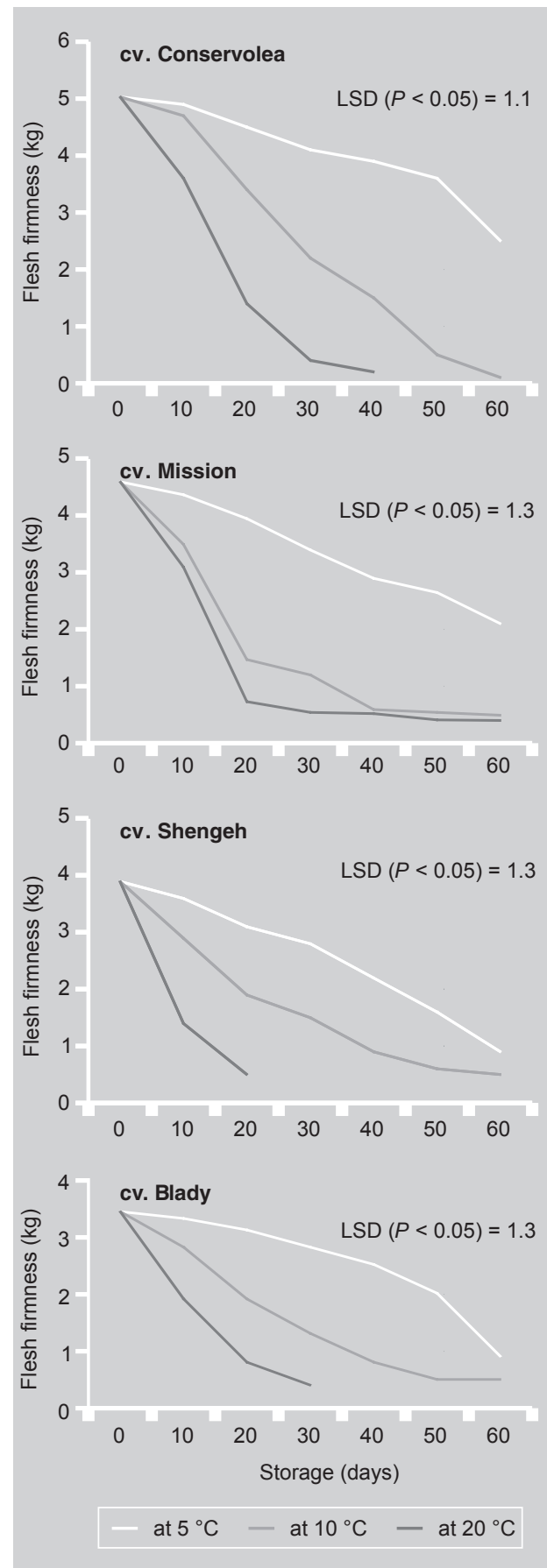

3. Results and discussion

Flesh firmness is probably the best predictor of olive storage life. Generally, storing olive fruits at $(5,10$ and 20$){ }^{\circ} \mathrm{C}$ caused a decrease in fruit firmness in all olive cultivars, but sof- tening was faster in fruits stored at (20 and 10) ${ }^{\circ} \mathrm{C}$ than in fruits stored at $5^{\circ} \mathrm{C}$ (figure 1). This is in agreement with the previous report of Agar et al. [19] on black ripe Manzanillo olives. Garcia and Streif [5] also observed a significant increase in flesh firmness of Gordal olives after prolonged cold storage. Olives stored for as long as $60 \mathrm{~d}$ at $5^{\circ} \mathrm{C}$ in air showed no symptoms of chilling injury in all cultivars.

The olive cultivar Conservolea retained satisfactory firm flesh above $2 \mathrm{~kg}$ for $60 \mathrm{~d}$ at $5^{\circ} \mathrm{C}, 30 \mathrm{~d}$ at $10^{\circ} \mathrm{C}$ or $15 \mathrm{~d}$ at $20^{\circ} \mathrm{C}$ (figure 1 ). The cultivars Mission, Blady and Shengeh showed that they reached the same flesh firmness as Conservolea a few days sooner (figure 1). During the first $10 \mathrm{~d}$ of storage at $20^{\circ} \mathrm{C}$, firmness of the green olives decreased from 30\% in cultivar Conservolea to $70 \%$ in cultivar Shengeh, and it was much lower than firmness of fruits stored at the other two temperatures. However, in all cultivars, olive fruit firmness was not significantly different in the $(5 \text { and } 10)^{\circ} \mathrm{C}$ treatments during the first $10 \mathrm{~d}$ of storage.

Changes in chlorophyll fluorescence $\left[\mathrm{F}_{\mathrm{v}} /\right.$ $\mathrm{F}_{\mathrm{m}}$ ] were observed during olive storage in all temperature treatments (figure 2). Except for $\mathrm{cv}$. Shengeh, the $\left[\mathrm{F}_{\mathrm{v}} / \mathrm{F}_{\mathrm{m}}\right]$ curve for all olive cultivars stored at $5{ }^{\circ} \mathrm{C}$ declined gradually until the end of the storage periods. For Mission, Conservolea and Blady olive cultivars stored at $10^{\circ} \mathrm{C},\left[\mathrm{F}_{\mathrm{v}} / \mathrm{F}_{\mathrm{m}}\right]$ declined with storage time from day 1 to day 60 , but the decline was rapid from day 30 to day 60 . The reduction in $\left[\mathrm{F}_{\mathrm{v}} / \mathrm{F}_{\mathrm{m}}\right]$ was fastest for $\mathrm{cv}$. Shengeh (figure 2). However, for olives stored at $20{ }^{\circ} \mathrm{C}$, a sharp decrease in $\left[\mathrm{F}_{\mathrm{v}} / \mathrm{F}_{\mathrm{m}}\right]$ was recorded for all cultivars tested in this experiment. The chlorophyll fluorescence technique has been found useful for predicting the postharvest storage life or keeping quality of a wide range of fruits and vegetables [18]. Early measurements used a sustained decrease in dark-adapted $\left[\mathrm{F}_{\mathrm{v}} / \mathrm{F}_{\mathrm{m}}\right]$ and an increase in $\left[\mathrm{F}_{\mathrm{v}} / \mathrm{F}_{\mathrm{m}}\right]$ to indicate the occurrence of photo-inhibitory damage in response to high temperature in McIntosh apple [20], chilling injury in banana and mango [21] and low $\mathrm{O}_{2}$ and/or high $\mathrm{CO}_{2}$ in controlled atmosphere storage [22-24]. In our study, for the first time, we are reporting on the application of the non-destructive 
method for evaluating postharvest assessment in olive cultivars.

In all olive cultivars, red skin color appeared to be greater at (10 and 20$)^{\circ} \mathrm{C}$ than at $5^{\circ} \mathrm{C}$, as shown by the increasing $a^{*}$ value measured (figure 3 ). Red color development did not progress much after $60 \mathrm{~d}$ when storing fruit at $5^{\circ} \mathrm{C}$; this temperature made it possible to observe a significant difference in the red skin color compared with the other temperature treatments and produced poorer color changes. Nevertheless, olives kept for $60 \mathrm{~d}$ at $5^{\circ} \mathrm{C}$ indicated that they were still marketable to very good for processing (figure 3). Shengeh olives stored at $5{ }^{\circ} \mathrm{C}$ developed greater red color than other olive cultivars. However, at $5{ }^{\circ} \mathrm{C}$, skin color remained green in the cultivars Mission, Blady and Conservolea (figure 3). Similar results were found with the changes in the $C^{*}$ and $H^{\circ}$ color indices (data not shown). Red color development is detrimental for these fruits as only green fruits can be processed with the Spanish method.

Decay incidence markedly increased with storage temperature from (10 to 20$)^{\circ} \mathrm{C}$ in cvs. Blady and Shengeh (figure 4). After $60 \mathrm{~d}$, Blady and Shengeh olives had (14 and $38) \%$ decay at $10{ }^{\circ} \mathrm{C}$, which increased to $(24$ and 51$) \%$ at $20^{\circ} \mathrm{C}$, respectively (figure 4 ). However, in the same time period, no decay was observed in Mission and Conservolea olives stored at either $(10 \text { or } 20)^{\circ} \mathrm{C}$. Also, no decay was observed in the four olive cultivars after $60 \mathrm{~d}$ of storage at $5^{\circ} \mathrm{C}$ (figure 4 ). Therefore, the four cultivars could be separated into two groups of high and no decay incidence: Blady and Shengeh cvs. with very high incidence of decay at either (10 or 20) ${ }^{\circ} \mathrm{C}$, but Conservolea and Mission cvs. with no decay, even after $60 \mathrm{~d}$ of storage at $20{ }^{\circ} \mathrm{C}$. Chilling injury, which can be a major cause of deterioration in fresh olives stored before processing, is described as internal browning around the pit or skin at advanced stages [25]. In our experiments, no visible chilling injury was observed, during the entire storage period, in any of the green olives of the four cultivars studied.

In the second year of the experiment, the results indicated that $1-\mathrm{MCP}$ treatment effectively reduced loss of firmness for fruit

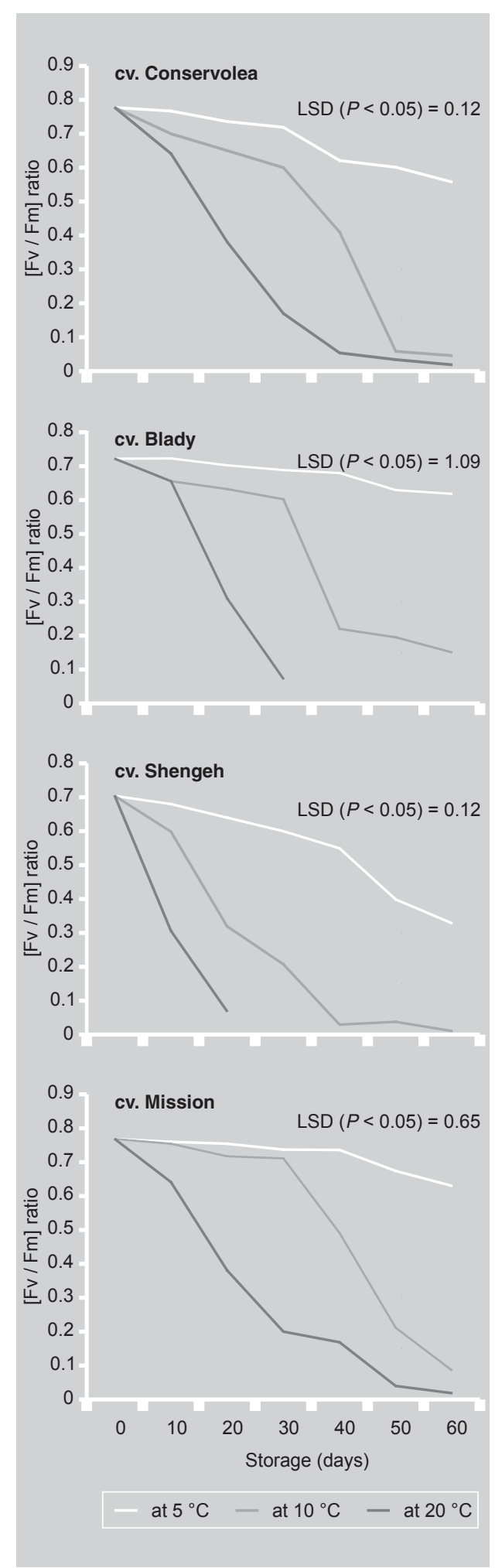

Figure 2.

Changes in chlorophyll fluorescence $\left[\mathrm{F}_{\mathrm{v}} / \mathrm{F}_{\mathrm{m}}\right]$ values of fruits from four olive cultivars during storage at three temperatures for $60 \mathrm{~d}$. 
Figure 3.

Changes in color values ( $a^{*}$ value) of olive skin before 10 and 20$)^{\circ} \mathrm{C}$ for four different varieties of fruits (Iran).

\section{Figure 4.}

Percentage of decay of fruits from four olive cultivars after $60 \mathrm{~d}$ of storage at three different temperatures (Iran). and after $60 \mathrm{~d}$ of storage at $(5$
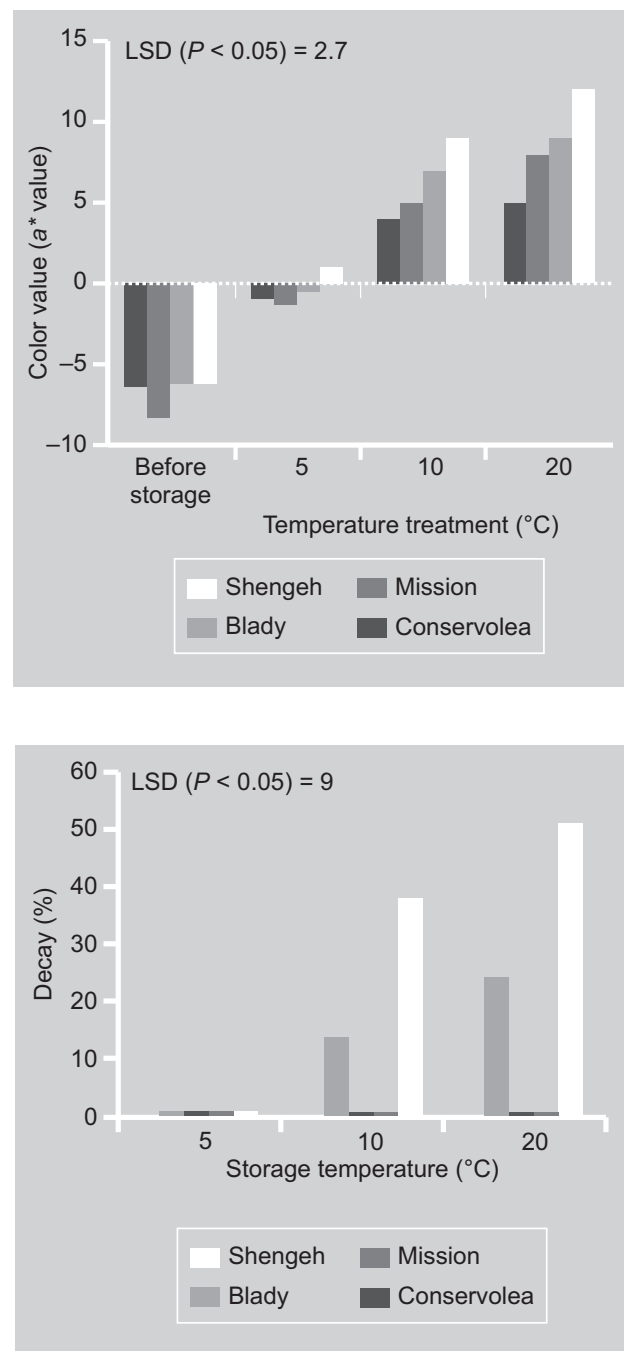

\section{Figure 5.}

Effects of 1-MCP treatments, applied for $24 \mathrm{~h}$ before a 15week storage period at $5{ }^{\circ} \mathrm{C}$, on fruit firmness for olives from four cultivars (Iran).

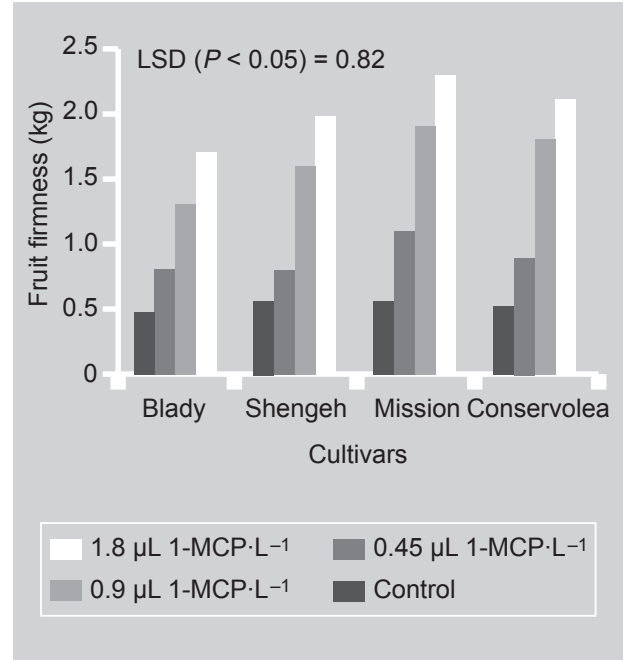

stored at $5{ }^{\circ} \mathrm{C}$. Untreated olives (control treatment) of the four cultivars placed at $5{ }^{\circ} \mathrm{C}$ after harvest reached their minimum flesh firmness after 15 weeks (figure 5). Then, they were considered very soft (fruit firmness $<0.6 \mathrm{~kg}$ ). Application of $0.9 \mu \mathrm{L} 1-\mathrm{MCP} \cdot \mathrm{L}^{-1}$ was sufficient to delay significantly $(P<$ 0.05 ) olive softening, compared with control untreated fruit (figure 5). Fruit treated with $1.8 \mu \mathrm{L} 1-\mathrm{MCP} \cdot \mathrm{L}^{-1}$ showed higher firmness values than those of fruit treated with $0.9 \mu \mathrm{L}$ $1-\mathrm{MCP} \cdot \mathrm{L}^{-1}$, but no significant difference was detected at the end of the storage period. However, there was no significant difference in firmness between fruit treated with $0.45 \mu \mathrm{L} 1-\mathrm{MCP} \cdot \mathrm{L}^{-1}$ and control fruits. In contrast, visible changes in olive skin color occurred after treating fruits with 1-MCP (figure 6 ) and storing them at $5^{\circ} \mathrm{C}$. The use of 1-MCP slowed down the change in $a^{*}$ values after treatment. Except for cv. Shengeh, $a^{*}$ values of 1 -MCP-treated fruits after 15 weeks of storage at $5{ }^{\circ} \mathrm{C}$ were significantly lower than $a^{*}$ values of control untreated fruits. Increasing the 1-MCP concentration from (0.9 to 1.8$) \mu \mathrm{L} 1-\mathrm{MCP} \cdot \mathrm{L}^{-1}$ should produce fewer changes in $a^{*}$ values, compared with those of control fruits (figure 6 ).

For consumers, fruit firmness and color after processing are much-appreciated sensorial attributes and sometimes the factors determining their acquisition. During ripening, color degradation and tissue softening occur, which are related to the reduced storage life. Use of 1-MCP was able to maintain fruit firmness and color for 15 weeks. This behavior seems to be a general effect of $1-\mathrm{MCP}$ in most of the studied fruits [26-28]. The background work for the discovery of $1-\mathrm{MCP}$ as an ethylene inhibitor came from the work of Sisler and Blankenship [29]. Given that 1-MCP blocks ethylene perception [30], it has the potential to prevent or slow limiting factors and processes to prevent the loss of storage life. 1-MCP will also protect plant products from both endogenous and exogenous sources of ethylene, which result in delaying senescence [13].

\section{Conclusion}

Conservolea, Mission and Blady olive cvs. can be stored for up to $60 \mathrm{~d}$ at $5^{\circ} \mathrm{C}$ and this could be extended to 15 weeks when fruits 
are treated with $(0.9$ and 1.8$) \mu \mathrm{L} 1-\mathrm{MCP} \cdot \mathrm{L}^{-1}$ before storage.

\section{Acknowledgements}

This work was supported by grants from the Iran National Science Foundation, Project No. 84203, which are gratefully acknowledged.

\section{References}

[1] Ferguson L., Sibbett G.S., Martin G., Olive production in California, Univ. Calif. Div. Agric. Natl. Resour., Publ. No. 3353, 1994.

[2] Garcia J.M., Gutierrez F., Barrera M.J., Albi M.A., Storage of mill olives on an industrial scale, J. Agric. Food Chem. 44 (1996) 590593.

[3] Garcia J.M., Gutierrez F., Castellano J.M., Perdiguero S., Albi M.A., Influence of storage temperature on fruit ripening and olive oil quality, J. Agric. Food Chem. 44 (1996) 264267.

[4] Olias J.M., Garcia J.M., Olive, in: Mitra S.K. (Ed.), Postharvest physiology and storage of tropical and subtropical fruits, CAB Int., Wallingford, UK, 1997, pp. 229-243.

[5] Garcia J.M., Streif J., The effect of controlled atmosphere storage on fruit quality of "Gordal" olives, Gartenbauwissenschaft 56 (1991) 233-238.

[6] Gutierrez F., Perdiguero S., Garcia J.M., Castellano J.M., Quality of oils from olives stored under controlled atmosphere, J. Am. Oil Chem. Soc. 69 (1992) 1215-1218.

[7] Maxie E.C., Storing olives under controlled temperature and atmospheres, Calif. Olive Assoc. Ann. Tech. Rep. 42 (1963) 34-40.

[8] Maxie E.C., Experiments on cold storage and controlled atmosphere, Calif. Olive Assoc. Ann. Tech. Rep. 43 (1964) 12-15.

[9] Kader A.A., Nanos G.D., Kerbel E.L., Storage potential of fresh "Manzanillo" olives, Callif. Agric. 40 (1990) 23-24.

[10] Kosiyachinda S., Young R.E., Chilling sensitivity of avocado fruit at different stages of the respiratory climacteric, J. Am. Soc. Hortic. Sci. 101 (1976) 665-667.

[11] Agar T., Hess-Pierce B., Sourour M.M., Kader A.A., Quality of fruit and oil of blackripe olives is influenced by cultivar and storage period, J. Agric. Food Chem. 46 (1998) 3415-3421.

[12] Nanos G.D., Kiritsakis A.K., Sfakiotakis E.M., Preprocessing storage conditions for green

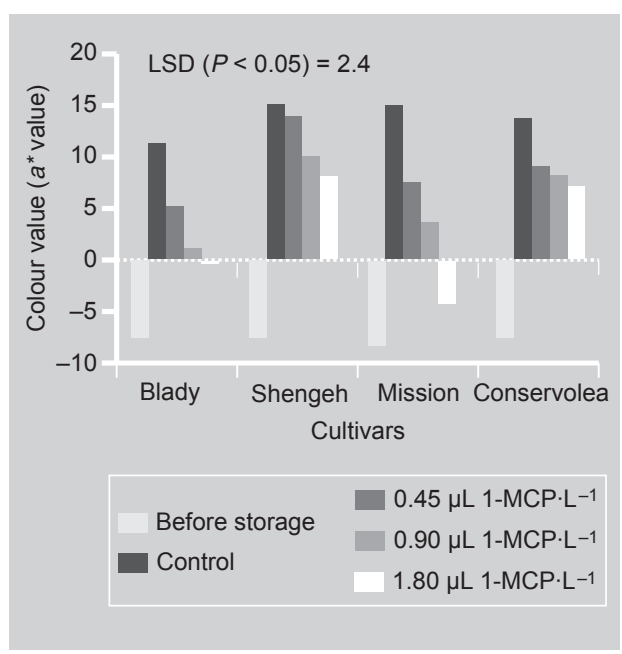

Figure 6.

Effects of 1-MCP treatments, applied for $24 \mathrm{~h}$ before a $15-$ week storage period at $5{ }^{\circ} \mathrm{C}$, on skin color values ( $a^{*}$ value) for fruits of four olive cultivars (Iran).

"Conservolea" and "Chondrolia" table olives, Postharvest Biol. Technol. 25 (2002) 109-115.

[13] Blankenship S.M., Dole J.M., Review 1methylcyclopropene, Postharvest Biol. Technol. 28 (2003) 1-25.

[14] Crisosto C.H., Kader A.A., Olive postharvest quality maintenance guidelines, Univ. Calif. Fresh prod. factsheet, 2005, pp. 1-5.

[15] Sisler E.C., Serek M., Inhibitions of ethylene responses in plants at the receptor level: recent developments, Postharvest Biol. Technol. 100 (1997) 577-582.

[16] Menniti A.M., Donati I., Gregori R., Response of 1-MCP application on plum stored under air and controlled atmospheres, Postharvest Biol. Technol. 39 (2006) 243-246.

[17] Abbott J.A., Quality measurement of fruits and vegetables, Postharvest Biol. Technol. 15 (1999) 207-225.

[18] DeEll J.R., van Kooten O., Prange R.K., Murr D.P., Applications of chlorophyll fluorescence techniques in postharvest physiology, Hortic. Rev., V. 23 (1999) 69-107.

[19] Agar J.T., Hess-Pierce B., Mohamed M., Sourour M.M., Kader A. A., Identification of optimum preprocessing storage conditions to maintain quality of black ripe "Manzanillo: olives, Postharvest Biol. Technol. 15 (1999) 53-64.

[20] DeEll J.R., Prange R.K., Murr D.P., Chlorophyll fluorescence as an indicator of apple fruit firmness, in: Proc. Int. Conf. Sensors for nondestructive testing: measuring the quality of fresh fruits and vegetables, Natural Resource, Agriculture and Engineering Service, Orlando, USA, 1997, pp. 67-73. 
[21] Smillie R.M., Hetherington S.E., Nott R., Chaplin G.R., Wade N.L., Application of chlorophyll fluorescence to the postharvest physiology and storage of mango and banana fruit and the chilling tolerance of mango cultivars, Asian Food J. 3 (1987) 55-59.

[22] Prange R.K., DeLong J.M., Leyte J.C., Harrison P.A., Oxygen concentration affects chlorophyll fluorescence in chlorophyll-containing fruit, Postharvest Biol. Technol. 24 (2002) 201-205.

[23] Prange R.K., DeLong J.M., Harrison P.A., Oxygen concentration affects chlorophyll fluorescence in chlorophyll-containing fruits and vegetables, J. Am. Soc. Hortic. Sci. 128 (2003) 603-607.

[24] DeLong J.M., Prange R.K., Leyte J.C., Harrison P.A., A new technology that determines low-oxygen thresholds in controlledatmosphere-stored apple, HortTechnol. 14 (2004) 262-266.

[25] Kader A.A., Olive disorders, Univ. Calif. Perish. Handl. Newsh. 86 (1996) 8-9.
[26] Watkins C.B., Nock J.F., Whitaker B.D., Response of early mid and late season apple cultivars to postharvest application of 1methylcyclopropene (1-MCP) under air and controlled atmosphere storage conditions, Postharvest Biol. Technol. 19 (2000) 17-32.

[27] Hofman P.J., Jobin-Décor M., Meiburg G.F., Macnish A.J., Joyce D.C., Ripening and quality responses of avocado, custard apple, mango and papaya fruit to 1-methylcyclopropene, Aust. J. Exp. Agric. 41 (2001) 567-572.

[28] Jeong J., Huber D.J., Sargent S.A., Influence of 1-methylcyclopropene (1-MCP) on ripening and cell-wall matrix polysaccharides of avocado (Persea americana) fruit, Postharvest Biol. Technol. 25 (2002) 241-264.

[29] Sisler E.C., Blankenship S.M., Methods of counteracting an ethylene response in plants, US Patent No. 5518 988, May 21, 1996.

[30] Sisler E.C., Serek M., Compounds controlling the ethylene receptor, Bot. Bull. Acad. Sci. 40 (1999) 1-7.

\section{Efectos de la temperatura de almacenamiento y de un tratamiento al 1-MCP en la calidad después de la cosecha de las olivas verdes.}

Resumen - Introducción. El tratamiento de la oliva en los países productores como Irán, a menudo no se sincroniza bien con su cosecha, a causa del número y del tamaño de las instalaciones dedicadas a la extracción del aceite. Tras su cosecha, las olivas pueden amontonarse y almacenarse a una temperatura ambiente durante varias semanas; y, en el transcurso de este periodo, se producen sendas deterioraciones. Consecuentemente, la industria de la transformación de la oliva verde está interesada en un pretratamiento que pueda sustituir este proceso por el almacenamiento de la oliva fresca. Material y métodos. Se cosecharon olivas verdes de los cvs. Blady, Conservolea, Mission y Shengeh en la fase verde maduro y almacenaron a $(5,10 \text { y } 20)^{\circ} \mathrm{C}$ durante $(10$ ou 15$)$ semanas para evaluar su fisiología después de la cosecha así como la evolución de su calidad. Durante un segundo año de experimento, se trataron olivas al 1-MCP empleado en las concentraciones de $(0,45,0,9$ y 1,8$) \mu \mathrm{L} \cdot \mathrm{L}^{-1}$ a $20^{\circ} \mathrm{C}$ durante $24 \mathrm{~h}$ y almacenadas a $5^{\circ} \mathrm{C}$. Se midió la calidad de las olivas periódicamente por la evolución del color de la piel, así como por la firmeza de la carne, la pérdida del peso y el deterioro de los frutos. Resultados y discusión. De modo general, el almacenamiento de las olivas a $(5,10 \text { y } 20)^{\circ} \mathrm{C}$ conllevó la disminución de la firmeza de la carne, pero el ablandamiento del fruto fue más rápido para los frutos almacenados a $(20 \text { y } 10)^{\circ} \mathrm{C}$ que para aquellos plazados a $5^{\circ} \mathrm{C}$. Las olivas almacenadas durante 60 días a $5^{\circ} \mathrm{C}$ no mostraron ningún síntoma de daños causados por el frío independientemente del cultivar. Las olivas de cultivares diferentes guardaron una carne firme aceptable durante 60 días a $5^{\circ} \mathrm{C}, 30$ días a $10{ }^{\circ} \mathrm{C}$ y 15 días a $20^{\circ} \mathrm{C}$. Tras 60 días de almacenamiento, el desarrollo del color rojo de la piel progresó poco en los frutos almacenados a $5{ }^{\circ} \mathrm{C}$, pero presentó diferencias significativas en otras temperaturas. Sin embargo la evolución del color rojo de la piel fue más intenso y más precoz para el cv. Shengeh que para los otros cultivares. En el segundo año de experimento, el tratamiento al 1-MCP redujo efectivamente el ablandecimiento de la carne para los frutos almacenados a $5{ }^{\circ} \mathrm{C}$ durante 15 semanas. Las aplicaciones $(0,9$ y 1,8$) \mu \mathrm{L} 1-\mathrm{MCP} \cdot \mathrm{L}^{-1}$ fueron suficientes para retrasar significativamente este ablandecimiento y el cambio de color de las olivas $(P<0.05)$, en comparación con las características de los frutos testigos no tratados. Conclusión. Las olivas de los cvs. Conservolea, Mission y Blady pueden almacenarse hasta 60 días a $5^{\circ} \mathrm{C}$ y su conservación podría prolongarse hasta 15 semanas si los frutos se tratasen con $\left(0,9\right.$ ó 1.8) $\mu \mathrm{L} 1-\mathrm{MCP} \cdot \mathrm{L}^{-1}$ antes de almacenamiento.

Iran República Islámica / Olea europaea / frutas / deterioro / almacenamiento / pérdidas postcosecha / temperatura ambiental / aptitud para la conservación 